\title{
SOCIO-ENVIRONMENTAL DISCLOSURE AND LEGITIMACY: AN INVESTIGATION OVER THE MAJOR BRAZILIAN BANKS
}

\author{
Juliana Costa Ribeiro Prates ${ }^{1}$ \\ Mestre em Contabilidade \\ Universidade Federal de Pernambuco \\ julianacrprates@gmail.com \\ Raimundo Nonato Rodrigues \\ Doutor em Contabilidade \\ Universidade Federal de Pernambuco \\ rnrdg@uol.com.br
}

\author{
Thierry Molnar Prates \\ Doutor em Desenvolvimento Econômico \\ Universidade Federal de Alagoas \\ thierry_prates@hotmail.com \\ Alexandra Cabral \\ Doutora em Engenharia de Produção \\ Universidade Federal de Alagoas \\ alexandra.cabral@feac.ufal.br
}

\begin{abstract}
This paper analyzes the relationship between sustainability and financial performances of the six biggest banks in Brazil. Brazilian banks were analyzed regarding their socio-environmental and economic disclosure. We collected socio-environmental data from annual reports, available on banks websites and financial data at Economática ${ }^{\circledR}$ database. Although disclosure data are not audited, which represents a limitation, these banks conduct their business in accordance with sustainable development policies and regulations, and publish information about initiatives. Methodological procedures include a content analysis, canonical correlation analysis and panel data regression providing a relationship assessment between variables. Results in this paper mostly showed a positive relationship between socio-environmental responsibility (SER) and financial performances, even considering the impacts of Brazilian crisis. The objective of this voluntary disclosure lays on companies' legitimacy as a dialogue mechanism with society.
\end{abstract}

Keywords: Banks; Brazil; Voluntary disclosure; Legitimacy theory; SER.

\section{INTRODUCTION}

The effects of the American subprime crisis in 2009 and the slow economic recovery resulted in greater skepticism about banking decision-making process. Throughout the crisis, and after that, banks (especially large ones) were heavily criticized for the impact of management decisions (SALTER, 2012; CORNETT; ERHEMJAMTS; TEHRANIAN, 2016). The heavy social burden of being literally saved by public funds meanwhile thousands of north

${ }^{1}$ Avenida dos Economistas, s/n, Centro de Ciências Sociais Aplicadas, Cidade Universitária, Recife/PE Recebido em 10/10/2018, revisões requeridas em 27/03/2019, aprovado em 08/05/2019, publicado em 30/08/2019 
americans were dumped from their homes for mortgage defaults, moved US banks to improve their social and environment disclosure, in order to seem socially relevant.

This misgiving effect was felt by banks all around the globe, since the crisis reached almost every country in the world and, in Brazil, in spite of its stronger financial regulation compared to US, a strong debate about banking intervention emerged, even before the crisis reach the local market and several months after the US and other rich countries. Brazil has a very concentrated banking structure, with 6 banks holding 84\% of the total assets in 2016 . Therefore, these big banks behave as an oligopoly keeping high interest rates even when Central Bank drops its rate. It could be counterintuitive, since banks have great monopoly power to determine prices and behave as they please, but our tests will show that are evidence about banking spending on voluntary disclosure, in an attempt to justify their huge profits.

Given the consequent economic insecurity banks, in Brazil and other parts of the world, are increasingly seeking for trust from shareholders and stakeholders, in order to legitimize themselves before society through transparency in resource management, disclosure of results, policies, practices, adoption of best corporate governance practices and voluntary disclosure of social and environmental information mechanisms (CHO; PATTEN, 2007). Hence, manifold regulatory and motivational mechanisms (monetary and non-monetary) have been discussed and implemented with the common objective of achieving better social management and accountability transparency.

The disclosure of socio-environmental responsibility actions and investments refers to companies' interactions with society and the environment. It is an important dialogue mechanism between them. Other authors complement that adapting corporate strategies to meet economic and social changes is a rational process that every successful company needs to undertake today (HOPWOOD; UNERMAN; FRIES, 2010). Thus, it is assumed that banks are able to influence the economy through its customers to become "greener", without sacrificing their financial return, reaching a positive image and therefore contributing to sustainable development.

At the same time that many efforts in recent years were engaged to enhance the sustainable development importance and awareness in companies, costumers demand for corporate socio-environmental responsibility (SER) grew up considerably (DE MELO et al., 2017). In addition, investors and stakeholders currently evaluate financial institutions by 
traditional and non-traditional metrics, as much as their socio-environmental commitment (FREEMAN; WICKS; PARMAR, 2004; JAMALI, 2008).

The main objective of this article is to investigate the relationship between financial and SER performance from 2010 to 2017, focusing on banks socio-environmental disclosure and its financial performance, mainly in crisis periods, and try to unveil their strategy to deal with this consequent liquidity excess. The paper has three parts beyond this introduction. The first presents a literature review and theoretical reference on socio-environmental responsibility, legitimacy theory and voluntary disclosure. In the second part, methodological analysis is described, and in the third part, the results are discussed regarding specific theories and impacts for Brazilian market.

\section{THEORETICAL FRAMEWORK}

\subsection{Background}

Brazilian banking institutions have their own regulation regarding socio-environmental (SER) commitment that they must comply with. According to National Monetary Council (CMN) Resolution 4.327/2014, the Social and Environmental Responsibility Policy (PRSA) report guarantees for companies and projects minimum of investments transparency, in which financial institutions invest. Moreover, these reports show how they apply management criteria in social and environmental investments. In order to operate well, the resolution requires each financial institution to define its own policy regarding the search to identify ways to mitigate the negative risks, such as bad reputation, caused from socio-environmental damages (HOPWOOD; UNERMAN; FRIES, 2010).

Globally, the banking sector began to embed environmental and social aspects into business from 1980's (CORNETT; ERHEMJAMTS; TEHRANIAN, 2016). Firstly, activities focused on internal environmental management (JEUCKEN; BOUMA, 2017) resulting in saving environmental resources, lower emissions and better reputation (BABIAK; TRENDAFILOVA, 2011). Secondly, banks incorporated environmental and social issues related to project finance, loans, investments, and assets management (SCHMIDHEINY; ZORRAQUIN, 1996; SCHOLTENS, 2009).

From the gradual embedding of sustainable attitudes, it has been found that environmental risks, such as those caused by climate change, can have a significant influence 
on credit risk and investment portfolio. In other words, emphasized is the perception that sustainability affects long-term business continuity (HOPWOOD; UNERMAN; FRIES, 2010).

Risks and opportunities need to be fully identified and managed (WEBER; SCHOLZ; MICHALIK, 2010; WEBER; HOQUE; ISLAM, 2015; ZEIDAN; BOECHAT; FLEURY, 2015). Consequently, many banks have implemented procedures of environmental credit risk assessment (WEBER, 2012). Finally, financial institutions have adopted socially responsible investment processes (SRI) to manage investments, risk and take advantage of opportunities (CERIN; SCHOLTENS, 2011).

Financial sector regulations focus primarily on the provision of risk-adjusted financial capital to ensure its stability (WEBER, 2017). Consequently, for long time, the pressure on the financial sector to have a responsible performance, regarding impacts of its main products and services, such as loans and investments, was lower than in many other industries (WEBER; DIAZ; SCHWEGLER, 2014). However, studies show that the environmental and sustainability report is positively correlated with the size and profitability of financial institutions (ALBERICI; QUERCI, 2016; CHIH; CHIH; CHEN, 2010), and the embedding of environmental aspects and issues of sustainability in products and services in the sector have increased over time (SCHOLTENS, 2009).

\subsection{LEGITIMACY THEORY}

In order to contribute to such embedding of social, environmental, economic and financial aspects in companies' everyday activities and in their decision-making process, companies adopt corporate social responsibility reporting models (CSR), which has contributed to their performance evaluation. Therefore, institutions that wish to enjoy a competitive advantage in market, choose voluntarily to disclose such data, since they are often not required to do so by law (SUTANTOPUTRA, 2009; HOPWOOD; UNERMAN; FRIES, 2010; DE MELO et al., 2017).

This study is based on legitimacy theory, on which companies disclose information of socio-environmental nature to show a positive and responsible image and legitimize their behavior for stakeholders and society. Derived from political economy, the theory of legitimacy is based on the idea that there is a "social contract" between companies and society, that is, symbolize the multiplicity of implicit and explicit society expectative about the organization operation (DEEGAN, 2002). 
Deegan (2002) supports the idea that the society holds the power to allow companies to exist and have rights, and in turn, it's necessary to realize and achieve their expectations in relation to how their operations should be conducted. Therefore, in order to survive, a company must ensure that the activities it performs are actually (or are perceived) in accordance with socially acceptable values and rules. When society's expectations are frustrated, there is a breach of contract and there may be a legitimacy gap.

In this sense, companies must not only comply with the parameters of legal requirements, but also respond to social demands and pressures. It is fundamental to their reputation that they have the ability to communicate to society its alignment with those values. Legitimacy theory show that social responsibility disclosures are related to industries with high public visibility or potentially more significant environmental impacts or, with less favorable public images that reveal more social responsibility information than their competitors (PATTEN, 1991; 2002; ADAMS; HILL; ROBERTS, 1998; TSANG, 1998; CLARKE; GIBSON-SWEET, 1999; BELL; BECK, 2004; PATTEN; CRAMPTON, 2004).

The legitimacy theory suggests that larger and more visible banks tend to disclose more socio-environmental information (PATTEN 1991; 2002; ADAMS; HILL; ROBERTS, 1998; TSANG, 1998; CLARKE; GIBSON-SWEET, 1999; BELL; BECK, 2004; PATTEN; CRAMPTON, 2004 and LOPES et al., 2017).

Current research such as Lopes et al., (2017) confirm that companies with high visibility or greater potential risk of negative impacts should express greater concern about improving corporate reputation, for this can be a positive influence on sales and is also an efficient mechanism to disseminate their socio-environmental responsibility. Thus, companies with higher potential environmental impact are more likely to provide environmental information for legitimacy reasons, and companies in sectors with higher consumer's visibility, such as banks, are more likely to consider important engagement with the community and disclose this information (CLARKE; GIBSON-SWEET, 1999). It can be anticipated, therefore, that a bank will have different disclosure practices in relation to environmental and community involvement, in comparison to that of an extractive industry company, with little visibility among the public, for example.

Therefore, the disclosure of environmental information can be used as a competitive differential by large banks. It is more likely to be important for companies with high visibility 
a positive social image through activities involving the community, partly because these activities can attract consumers but also can justify their existence.

\subsection{VOLUNTARY DISCLOSURE}

The disclosure of socio-environmental information was broadly defined as a communication process to stakeholders and society, about socio-environmental impacts arising from the organization's economic actions (GRAY; OWEN; ADAMS, 1996). Thus, the need to analyze several socio-environmental aspects is emphasized, on which the company's activities can have an impact: employee issues, community involvement, environmental concerns, other ethical issues, etc. Tinker and Neimark (1987) argue that society demands investments from companies to avoid and repair environment damage, to ensure consumers and employees health and safety, and those living in communities where products are manufactured, and waste are dumped. As a result, companies with poor socio-environmental performance increasingly find difficulties to obtain the necessary resources and support to remain operating within a community that appreciate a clean environment.

This kind of information report is the subject of some studies carried out between 1998 and 2004. The internet was analyzed as a tool for communicating with stakeholders and an easy way of spreading social responsibility with increasing numbers (ESROCK; LEICHTY, 1998; 2000; WILLIAMS, 1999; MAIGNAN; RALSTON, 2002; PATTEN, 2002; COOPER, 2003; SNIDER; HILL; MARTIN, 2003; CAMPBELL; BECK, 2004; DOUGLAS; DORIS; JOHNSON, 2004). The benefits of the Internet regarding traditional communication channels are substantially related to its interactive nature, with the possibility of disseminating more information in a fast and economic way (CASTELO BRANCO; LIMA RODRIGUES, 2006). The internet allows companies to provide information for different stakeholders and obtain feedback. As pointed out by Esrock and Leichty (2000), differently of traditional mass media channels, a single website can include multiple sections, each one targeting a different audience, and currently include the annual reports already incorporating socio-environmental aspects.

Comparing to other sectors such as chemicals, pulp and paper, etc., the financial services sector has a significantly lower direct environmental impact. Therefore, it's used as an argument for excluding banks and finance companies from studies which analyze all the components of the social responsibility disclosure (ARCHEL DOMENCH, 2003). However, there are strong arguments for its inclusion. Thompson and Cowton (2004) argue that banks can be facilitators of industrial activities, which can cause environmental damage. Thus, banking and financial 
companies' activities, such as their lending and investment policies, can be considered equally sensitive to the environment, comparing to direct impacts of polluting industries (CASTELO BRANCO; LIMA RODRIGUES, 2006).

Banks can report what they are doing to avoid fostering, through their lending and investment policies, industrial activities that are harmful to the environment. Thereby, these banks can mitigate possible reputational impacts from lending with significant environmental impacts risks. In addition, financial institutions consume large amounts of resources, such as paper and energy, and are often considered as having a significant environmental impact for its waste (CASTELO BRANCO; LIMA RODRIGUES, 2006; HOPWOOD; UNERMAN; FRIES, 2010). Therefore, policies to reduce energy consumption, less use of natural resources, and recycling activities are core aspects for its social responsibility image.

Two strands regarding voluntary disclosure of socio-environmental information are worth of mention. On the one hand, it is emphasized that sustainability reports it's a public interest demand and brings sustainable development mentality among the main agents of change. Moreover, these reports promote more transparency in the critical and relevant environmental, social and economic impacts, providing information used by the market to undertake holistical decisions (HOPWOOD; UNERMAN; FRIES, 2010). On the other hand, the second strand claims that voluntary disclosure of socio-environmental information brings considerable benefits in terms of corporate reputation and competitiveness, involving the reduction of information asymmetry and risk regarding the investors (ROVER et al., 2012; CARDOSO; DE LUCA; GALLON, 2014; HOMERO JUNIOR, 2017).

Information provision and associated management practices, enables organizations and their stakeholders to identify, understand, evaluate, incorporate and report economic, socioenvironmental issues, with the same level of importance and in an integrated way, and thus, contribute for the economy and society sustainable development (HOPWOOD; UNERMAN; FRIES, 2010). As a caveat, it is currently dialogued that the use of these reports as a form of greenwashing, or reputation manipulation, since some information is not audited.

Recently researches as De Jong, Harkink and Barth (2018) highlight greenwashing effects of socio-environmental disclosure and initiatives. The consumer perception survey shows that, greenwashing contributes to the organization perceived environmental performance, but the benefit appears to be short-term and doesn't seem to be important influencing consumer buying. On the other hand, greenwashing threatens consumer's 
perception about the organization's communication integrity. This is a potentially serious threat both to specific organizations and to the entire SER initiatives system (ALVES, 2009; ELVING; VAN VUUREN, 2011). In summary, it does not seem to contribute to consumers' buying interests, so it can be a futile and myopic strategy.

Tarna (1999) studied environmental reports from 12 banks and insurance companies and found the reports groups target: shareholders, customers and employees. All reports included information about material and energy flows generated by corporate operations, energy, paper, water, waste, emissions - and ecologic products - environmental risks management related to financial products and specific environmental products, such as green investment, products, or ethical and project financing and environmentally friendly investments.

The research developed by Cornett, Erhemjamts and Tehranian (2016) involving US commercial banks has shown that after the 2008 financial crisis the biggest banks, target of major criticism due to a lack of social awareness, tried to improve their CSR activities. Despite the "too big to fail" status of these banks, the crisis demanded banks and stakeholders improve their CSR policies.

The recent literature states that companies seek raise profits with CSR's maximization (FATEMI; FOOLADI; WEELER, 2009; BÉNABOU; TIROLE, 2010; GILLAN et al., 2010; GARCIA-CASTRO; ARIÑO; CANELA, 2010; SERVAES; TAMAYO, 2013; FATEMI; FOOLADI, 2013; DIMSON; KARAKAS; LI, 2015). Besides, commitment to CSR means higher profitability, lower capital cost, higher competitiveness and better reputation (EL GHOUL et al., 2011; GOSS; ROBERTS, 2011; JO; HARJOTO, 2011). Hence, this paper aims to measure the relationship between CSR behavior and corporate financial performance in the Brazilian banking context from 2010 to 2017.

\section{METHODOLOGICAL PROCEDURES}

\subsection{Research Design and Sample}

This is a quantitative research developed through canonical correlation technique and data panel, we analyzed information from banks published annual reports (which are part of the sample). Besides, we expose the banks socio-environmental performance under two perspectives: first, analyzing the relationship between environmental and financial performances; then, complementarily, the behavioral pattern of these investments in a crisis 
context, with steady profits and bank increasing liquidity, even under an economic recession in Brazil.

The sample consists of six of the ten largest Brazilian banks: Itaú-Unibanco, Bradesco, Banco do Brasil, Caixa Econômica Federal, Santander and Citibank, which portray $87 \%$ of all bank deposits - 2016 - and owned 90\% of branches in Brazil (BACEN, 2016). Besides, the first three mentioned banks were ranked among the forty-three biggest financial institutions worldwide by Forbes Magazine ${ }^{2}$. The sampling process is non-probabilistic, since it starts from a naturally restricted universe, respecting the information availability and accessibility necessary for the present work. It brings some inference limitations, but does not invalidate the results, since we do not intent to make generalizations for small banks.

Concerning to reputation, these banks are listed on B3 sustainability indexes, for instance ICO2 and ISE which represents a positive correlation between voluntary disclosure and a better reputation, except for Caixa Econômica Federal and Citibank (CARDOSO; DE LUCA; GALLON, 2014). Besides, only the six banks listed on our sample provide GEE emission inventory by GHG Protocol, regardless negative externalities involved.

The main objective is to assess the relationship between socio-environmental performance and financial performance in Brazilian banks context, over the chosen period (LIANG; ZEGER, 1986).

\subsection{Period and chosen variables}

The analysis was carried out from 2010 to 2017. Altogether six variables were chosen. The dependent variable represents sustainability initiatives voluntarily published by banks, henceforth it will be called SER. This variable is a proxy of voluntary disclosure captured and encompasses the social and environmental dimensions of each bank considering initiatives publicized on the internet (ELKINGTON, 1999).

In order to collect socio-environmental initiatives data, a content analysis was made, including financial and non-financial reports: annual, administration documents and sustainability from websites of the respective banks. We hand-collect all SER data advertised by banks, on issues involving social and environmental aspects: internal ${ }^{3}$, external ${ }^{4}$ and socio-

\footnotetext{
${ }^{2}$ The Forbes global ranking is based on revenue, market value, assets and profit. According to its websites, these banks run their business with sustainable development policies and regulations and publish information related to financial, environmental, social aspects.

${ }^{3}$ Benefits related to employees eg. Nutrition, training, profit-sharing, medical care.

${ }^{4}$ Back to the external community eg. sponsorships in education, culture, health, sport
} 
environmental initiatives ${ }^{5}$. However, SER data are limited to each bank voluntary way of disclosure, whereas there is no regulated publishing pattern.

This study presents an exploratory approach using the canonical correlation technique for dependent variable identification. Furthermore, we build two control variables, namely: banks liquidity and annual stock prices, which represents the investors view in a 8 years period that includes a Brazilian crisis (BRAMMER; BROOKS; PAVELIN, 2006).

The model is specified with five financial indicators as independent variables, namely: Total Assets, Net Income, Return on Equity-ROE, which have been considered by some authors, (CORNETT; ERHEMJAMTS; TEHRANIAN, 2016). Financial data was gathered from Economática ${ }^{\circledR}$ database. All variables considered in this paper are described on Table 1.

Table 1 - Variables Description

\begin{tabular}{|c|c|c|c|}
\hline Variable & Description & Source & Unit \\
\hline $\mathrm{SER}_{\mathrm{i}, \mathrm{t}}$ & $\begin{array}{l}\text { Dependent variable, represented by socio environmental report } \\
\text { of bank } i \text {, at year } t \text {. }\end{array}$ & Annual reports & $\mathrm{R} \$$ \\
\hline $\mathrm{SER}_{\mathrm{i}, \mathrm{t+1}}$ & $\begin{array}{l}\text { Dependent variable, represented by socio environmental report } \\
\text { of bank } i \text {, at year } t+l \text {. }\end{array}$ & Annual reports & $\mathrm{R} \$$ \\
\hline $\mathrm{TA}_{i, t}$ & $\begin{array}{l}\text { Independent variable, represented by total assets of bank } i \text {, at } \\
\text { year } t\end{array}$ & Economatica* & $\mathrm{R} \$ 1.000$ \\
\hline $\mathrm{NI}_{i, t}$ & $\begin{array}{l}\text { Independent variable, represented by net income of bank } i \text {, at } \\
\text { year } t\end{array}$ & Economatica* & $\mathrm{R} \$ 1.000$ \\
\hline $\mathrm{ROE}_{i, t}$ & $\begin{array}{l}\text { Independent variable, represented by the return on equity (ratio } \\
\text { between net operating income and average equity) of bank } i \text {, at } \\
\text { year } t\end{array}$ & Economatic* & $\%$ \\
\hline $\mathrm{LQ}_{i, t}$ & $\begin{array}{l}\text { Independent variable, represented by the quotient between } \\
\text { availabilities and deposits of bank } i \text {, at year } t\end{array}$ & Economatica* & $\mathrm{R} \$ 1.000$ \\
\hline $\mathrm{STOCK}_{i, t}$ & $\begin{array}{l}\text { Independent variable, represented by the annual stock return } \\
\text { price of bank } i \text {, at year } t\end{array}$ & Economatica* & $\%$ \\
\hline
\end{tabular}

Source: Research data

Note: *available at https://economatica.com/.

\subsection{Statistical procedures}

The analysis was conducted in three stages: firstly, canonical analysis, assessing SER variable at current period $\left(S E R_{i, t}\right)$, and in the next one $S E R_{i, t+1}$. The objective of this multivariate technic is to identify one appropriated dependent variable for panel estimation

\footnotetext{
${ }^{5}$ Initiatives in programs related to the environment and its natural resources
} 
(MARTINS; MONTE, 2015). Hence, the highest correlation between SER dependent variables and canonical loadings determine which one fits the better. Secondly, after identifying the dependent variable, we estimate a static panel model in order to analyze how each independent variables influences the dependent variable of socio-environmental performance. Finally, we evaluate the effects of the Brazilian banks' financial performance on SER performance.

\subsubsection{Canonical Correlation Analysis}

Canonical correlation analysis is a method for mesuring the relationship between two multivariate sets of variables, all measured for the same company (HAIR, 2006). In this study, two groups of variables are measured: the relationship between SER and financial performance variables.

Canonical correlation analysis will describe the relationship between the first set of variables $\left(S E R_{i, t}\right.$ and $\left.S E R_{i, t+1}\right)$ and the second set of variables $\left(\mathrm{TA}_{i, t}, \mathrm{NI}_{i, t}, \mathrm{ROE}_{i, t}, \mathrm{LQ}_{i, t}\right.$ and STOCK $_{i, t}$, ). The canonical correlation model is described by Equation 1.

$S E R_{i, t}+S E R_{i, t+1}=T A_{i, t}+N I_{i, t}+R O E_{i, t}+L Q_{i, t}+S T O C K_{i, t}$

Where:

$\mathrm{SER}_{\mathrm{i}, \mathrm{t}}$ is the socio-environmental performance of bank $i$, at year $t$;

$\mathrm{SER}_{\mathrm{i}, \mathrm{t}+1}=$ socio-environmental performance of bank $i$, at year $t+1$;

$\mathrm{TA}_{i, t}=$ total assets of bank $i$, at year $t ; \mathrm{NI}_{i, t}=$ net income of bank $i$, at year $t$;

$\mathrm{ROE}_{i, t}=$ return on equity of bank $i$, at year $t$;

$\mathrm{LQ}_{i, t}=$ quotient between availabilities and deposits of bank $i$, at year $t$;

$\mathrm{STOCK}_{i, t}=$ annual stock return price of bank $\mathrm{i}$, at year $\mathrm{t}$.

\subsubsection{Panel Regression}

The econometric model estimated is an unbalanced data panel, with 6 banks, from 2010 to 2017, as follows:

$S E R_{i, t+1}=\alpha_{o}+T A_{i, t}+N I_{i, t}+R O E_{i, t}+L Q_{i, t}+S T O C K_{i, t}+u_{i, t}$

Where, 
$i=1$ to $n$ is the bank index and $t=1$ to $\mathrm{T}$ is the time index

$\mathrm{SER}_{\mathrm{i}, \mathrm{t}}=$ socio environmental report of bank $i$, at year $t$.

SER $_{\mathrm{i}, t+1}=$ socio environmental report of bank $i$, at year $t+1$.

$\mathrm{TA}_{i, t}=$ total assets of bank $i$, at year $t$

$\mathrm{NI}_{i, t}=$ net income of bank $i$, at year $t$

$\mathrm{ROE}_{i, t}=$ return on equity of bank $i$, at year $t$

$\mathrm{LQ}_{i, t}=$ quotient between availabilities and deposits of bank $i$, at year $t$

$\mathrm{STOCK}_{i, t}=$ annual stock return price of bank $\mathrm{i}$, at year $\mathrm{t}$

$u_{i t}$ a random disturbance term of mean 0 .

The variables expected behavior, according to the literature, is disposed on Table 2.

Table 2 - Variables expected behavior

\begin{tabular}{c|c}
\hline $\begin{array}{c}\text { Independent } \\
\text { Variables }\end{array}$ & Expected Relationship \\
\hline $\mathrm{TA}_{i, t}$ & + \\
$\mathrm{NI}_{i, t}$ & + \\
$\mathrm{ROE}_{i, t}$ & $+/-$ \\
$\mathrm{LQ}_{i, t}$ & $+/-$ \\
$\mathrm{STOCK}_{i, t}$ & $+/-$ \\
\hline \multicolumn{2}{l}{ Source: Research data. }
\end{tabular}

\section{RESULTS AND DATA ANALYSIS}

\subsection{Canonical correlation results}

The identification of the SER dependent variable that best fits the econometric model was performed as follows: initially, we verified the canonical function that best maximizes the correlation between the two sets of variables; secondly, through canonical weights and structural correlation (loads) it was verified which of the dependent variables most contributes to the canonical variable.

We obtained two canonical functions, whose significance tests joint are shown in Table 3. As can be seen, the p-value of all the statistics shown on Table 3 are less than $1 \%$, therefore we can reject the idea that canonical functions are not significant. The results indicates that at least one of the functions is significant at the $1 \%$ level, thus expressing the relation between the sets of variables.

Table 3 - Results of multivariate significance tests

\begin{tabular}{c|c|c}
\hline Test & Statistic & $\boldsymbol{p}$-value \\
\hline Wilks' Lambda & 0,1795832 & 0,000 \\
Pillai's trace & 0,6949668 & 0,001 \\
Lawley-Hotelling trace & 3,8487217 & 0,000 \\
Roy's largest root & 0,7850213 & 0,000 \\
\hline Source: Research data.
\end{tabular}


Variables canonical loadings are presented on Table 4. The canonical loadings are similar to the standardized coefficients of a multiple regression, that is, they indicate how much a variable contributes for the canonical variable shaping. As can be seen, between the dependent variables, the one that presented the greatest influence on the formation of the canonical variable was $\operatorname{SER}_{i, t+1}$.

Since the objective of using canonical correlation was restricted to the identification of the most adequate dependent variable to the set of variables, the $\mathrm{SER}_{\mathrm{t}+1}$ was chosen as the dependent variable in the analysis that will be presented in the sequence.

Table 4 - Loadings between original variables and canonical variables.

\begin{tabular}{c|c|c|c}
\hline Dependent Variables & Function 1 & Independent Variables & Function 1 \\
\hline SER $_{t}$ & 0,837 & $\mathrm{TA}_{\mathrm{t}}$ & $-0,096$ \\
$\mathrm{SER}_{\mathrm{t}+1}$ & 0,937 & $\mathrm{NI}_{\mathrm{t}}$ & $-0,185$ \\
& & $\mathrm{ROE}_{\mathrm{t}}$ & $-0,047$ \\
& & $\mathrm{LQ}_{\mathrm{t}}$ & 0,303 \\
& & $\mathrm{STOCK}_{\mathrm{t}}$ & $-0,502$ \\
\hline
\end{tabular}

Source: Research data.

\subsection{Panel data results}

The results of the proposed econometric model were obtained using the computational platform R. It was decided to work with the routine ppgls () since the random modeling was the best according to the Hausman statistical test ( $\mathrm{p}$-value $=0,1581$ ). Table 5 shows the summary of the results obtained.

Table 5 - Sensitivity of SER to financial performance variables

\begin{tabular}{c|c|c|c}
\hline Variables & Estimate & Std. Error & $\boldsymbol{p}$-value \\
\hline Intercept & $-76,296$ & 12,193 & 0,0000 \\
$\mathrm{TA}_{\mathrm{t}}$ & 5,594 & 1,271 & 0,0000 \\
$\mathrm{NI}_{\mathrm{t}}$ & $-2,144$ & 2,038 & 0,2929 \\
$\mathrm{ROE}_{\mathrm{t}}$ & 4,139 & 1,189 & 0,0005 \\
$\mathrm{LQ}_{\mathrm{t}}$ & 8,469 & 2,526 & 0,0008 \\
STOCK $_{\mathrm{t}}$ & $-0,113$ & 0,168 & 0,5013 \\
\hline
\end{tabular}

Source: Research data.

The estimation model shows neither heteroskedasticity nor autocorrelation (Table 6). 
Socio-environmental disclosure and legitimacy: an investigation over the major brazilian banks

Table 6 - Statistical tests results of heteroskedasticity and autocorrelation

\begin{tabular}{l|c|c|c}
\multicolumn{1}{c|}{ Variables } & Estimate & $\begin{array}{c}\text { Degrees of } \\
\text { freedom }\end{array}$ & $\boldsymbol{p}$-value \\
\hline Breusch-Pagan test for heteroskedasticity & 2,7706 & 5 & 0,7353 \\
Breuch-Godfrey/Wooldridge test for serial correlation & 0,2035 & 1 & 0,6519 \\
in idiosyncratic errors & 15,672 & 10 & 0,1094 \\
Breusch-Pagan LM test for cross sectional dependence & 0,0122 & Not pertinent & 0,9903 \\
Pesaran CD test for cross sectional dependence &
\end{tabular}

Source: Research data.

The model presented a $\mathrm{R}^{2}$ of 0.81 , which can be considered high. Table 5 shows that, two out of five independent variables were not statistically significant (NI and STOCK). Therefore, nothing can be inferred about its influence on socioenvironmental investments (SER). The remaining variables were statistically significant at $1 \%$ level.

Regarding the variable TA, it can be observed that a $1 \%$ increase on it for a given bank causes a 5.6\% increase in its socio-environmental investments, which means that such investments are considerably positive and sensitive to bank size. The ROE variable also behaved similarly to TA and is positively related to SER.

The LQ variable, when raised by $1 \%$, generates the highest increase of all, $8.47 \%$ growth in SER. Showing that the greater the growth of bank liquidity, the greater the impact on social and environmental investments, even in the midst of Brazilian crisis. This result confirms several international findings which have investigated the same subject. Finally, the variables behavior (from Table 2) was as expected.

\section{FINAL CONSIDERATIONS}

This paper aimed to analyze the impact of banks financial performance on social and environmental initiatives (SER), from 2010 to 2017, which comprise the Brazilian crisis. To achieve this objective, we resort methodological procedures such as content analysis, multivariate technique of canonical correlation and panel data.

The growing evolution of SER practices and disclosures fostered researches on these initiatives and its relationship with companies' financial performance. Several recent researches has provided mixed results about these effects (Jiao, 2010). Most of the literature focuses on measuring financial performance based on market. Just a few studies examine the capital market perceptions about such initiatives (EL GHOUL et al., 2011).

Our results show that under Brazilian crisis, SER was higher. Cornett, Erhemjamts and Tehranian (2016) found the same about banks concerns on reputation impact due to 2008 
financial crisis, period in which banks increased SER. Moreover, our results for Brazil include a control variable named Liquidity, and it is positive correlated to SER. This result means that major Brazilian banks, are concerned with their clients, shareholders and stakeholders' longterm trust, reputation and image, adopting social and environmental responsibility initiatives. In addition, it seems that when banks reach their financial success goals, thereafter they meet socio-environmental targets.

Socio-environmental initiatives disclosure is currently under discussion regarding reputation manipulation, which can promote short term success. However, De Jong, Harkink and Barth (2018) argue that this myopic attitude does not seem to fit for big banks.

Our findings show that corporate SER and financial performances are positively correlated, despite the crisis. Our results acknowledge the three dimensions interdependence: social, environmental and financial, in accordance with Weber (2017) study about the Chinese banks.

Regardless the results suggest no inference at the moment between SER and shares return or net income, we cannot infer that SER are not important through investors' eyes.

The main purpose for big banks socio-environmental investment in Brazil today lays on the fact that they need recognition and self-legitimacy over society. The pointed out facts raise to discussion the role of banks in society. Furthermore, the vicious institutional structure given by lack of disclosure regulation, foster Brazilian big banks to prevent costumers indignation against the massive amount of profits they make with nothing in return.

In this sense, one answer for the main question of the present research would be that banks try to avoid risks of structural change, which would enlarge competition and drop profits through taxation. Thereby, they must show their social responsibility and advertise it, even though the accuracy and control of the reported numbers are dubious.

Jiao (2010) points out that the positive effect of SER on corporate performance is consistent with the view that SER represents an intangible asset investment, such as reputation and human capital, which contribute to increasing companies' competitiveness. SER's initiatives represent the growing banks concern with their reputation and competitiveness, answering to public pressure for social and environmental responsibility, and also to comply with legal requirements and specific regulations.

The results of the present study add scientific knowledge, since they jointly address issues of voluntary disclosure, social and environmental investments, corporate reputation, 
bank liquidity and crisis environment. The association of these variables brings important information to subsidize the actions of the Brazilian banks about socio-environmental responsibility, revealing a positive relation between variables and ratify the search for legitimization in a crisis context.

The sample size, the scarce number of indicators of financial performance and pattern lack of socio-environmental disclosure are the research limitations. However, for the analyzed banks it was possible to get some evidence about the relationship between socio-environmental and financial performance in Brazil. In addition, we know that socio-environmental actions and initiatives inside the annual reports are incomplete, only the information with greater relevance and materiality are included (HOPWOOD; UNERMAN; FRIES, 2010). Therefore, a future research field can be an analysis of shareholders and customers' perception about corporate social responsibility, and how these initiatives can reduce information asymmetry.

\section{REFERENCES}

ADAMS, Carol A.; HILL, Wan-Ying; ROBERTS, Clare B. Corporate social reporting practices in Western Europe: legitimating corporate behaviour? The British accounting review, v. 30, n. 1, p. 1-21, 1998.

ALBERICI, Adalberto; QUERCI, Francesca. The quality of disclosures on environmental policy: The profile of financial intermediaries. Corporate Social Responsibility and Environmental Management, v. 23, n. 5, p. 283-296, 2016.

ALVES, Igor M. Green spin everywhere: how greenwashing reveals the limits of the csr paradigm. Journal of Global Change \& Governance, v. 2, n. 1, 2009.

BABIAK, Kathy; TRENDAFILOVA, Sylvia. CSR and environmental responsibility: motives and pressures to adopt green management practices. Corporate social responsibility and environmental management, v. 18, n. 1, p. 11-24, 2011.

BANCO CENTRAL DO BRASIL - BACEN. Disponível em: https://www.bcb.gov.br/?id=REVSFN\&ano=2016

BÉNABOU, Roland; TIROLE, Jean. Individual and corporate social responsibility. Economica, v. 77, n. 305, p. 1-19, 2010.

BRAMMER, Stephen; BROOKS, Chris; PAVELIN, Stephen. Corporate social performance and stock returns: UK evidence from disaggregate measures. Financial management, v. 35, n. 3, p. 97-116, 2006.

CAMPBELL, David; CORNELIA BECK, A. Answering allegations: The use of the corporate website for restorative ethical and social disclosure. Business Ethics: A European Review, v. 13, n. 2-3, p. 100-116, 2004. 
CARDOSO, Vanessa Ingrid et al. Reputação corporativa nas empresas brasileiras: uma questão relevante para o desempenho empresarial? Revista Contemporânea de Contabilidade, v. 10, n. 21, p. 115-136, 2013.

CARDOSO, V. I. C.; DE LUCA, M. M. M.; GALLON, A. V. Reputação corporativa e o disclosure socioambiental de empresas brasileiras. Contabilidade, Gestão e Governança, v. 17, n. 2, p. 26-25, 2014.

CASTELO BRANCO, Manuel; LIMA RODRIGUES, Lúcia. Communication of corporate social responsibility by Portuguese banks: A legitimacy theory perspective. Corporate Communications: An International Journal, v. 11, n. 3, p. 232-248, 2006.

CERIN, Pontus; SCHOLTENS, Bert. Linking responsible investments to societal influence: motives, assessments and risks. Sustainable Development, v. 19, n. 2, p. 71-76, 2011.

CHIH, Hsiang-Lin; CHIH, Hsiang-Hsuan; CHEN, Tzu-Yin. On the determinants of corporate social responsibility: International evidence on the financial industry. Journal of Business Ethics, v. 93, n. 1, p. 115-135, 2010.

CHO, Charles H.; PATTEN, Dennis M. The role of environmental disclosures as tools of legitimacy: A research note. Accounting, organizations and society, v. 32, n. 7-8, p. 639647, 2007.

CLARKE, Julia; GIBSON-SWEET, Monica. The use of corporate social disclosures in the management of reputation and legitimacy: a cross sectoral analysis of UK Top 100 Companies. Business Ethics: A European Review, v. 8, n. 1, p. 5-13, 1999.

COOPER, Stuart Martin. Stakeholder communication and the Internet in UK electricity companies. Managerial Auditing Journal, v. 18, n. 3, p. 232-243, 2003.

CORNETT, Marcia Millon; ERHEMJAMTS, Otgontsetseg; TEHRANIAN, Hassan. Greed or good deeds: An examination of the relation between corporate social responsibility and the financial performance of US commercial banks around the financial crisis. Journal of Banking \& Finance, v. 70, p. 137-159, 2016.

DEEGAN, Craig. Introduction: The legitimising effect of social and environmental disclosures-a theoretical foundation. Accounting, Auditing \& Accountability Journal, v. 15, n. 3, p. 282-311, 2002.

DE JONG, Menno DT; HARKINK, Karen M.; BARTH, Susanne. Making Green Stuff? Effects of Corporate Greenwashing on Consumers. Journal of business and technical communication, v. 32, n. 1, p. 77-112, 2018.

DE MELO, Flávio José et al. Gestão socioambiental em instituições bancárias no brasil: uma análise a luz dos relatórios anuais de sustentabilidade. Contabilidade Vista \& Revista, v. 28, n. 1, p. 117-140, 2017. 
DIMSON, Elroy; KARAKAŞ, Oğuzhan; LI, Xi. Active ownership. The Review of Financial Studies, v. 28, n. 12, p. 3225-3268, 2015.

DOMENCH, Pablo Archel. La divulgación de la información social y medioambiental de la gran empresa española en el período 1994-1998: situación actual y perspectivas. Spanish Journal of Finance and Accounting/Revista Española de financiación y contabilidad, v. 32, n. 117, p. 571-601, 2003.

DOUGLAS, Alex; DORIS, John; JOHNSON, Brian. Corporate social reporting in Irish financial institutions. The TQM Magazine, v. 16, n. 6, p. 387-395, 2004.

EL GHOUL, Sadok et al. Does corporate social responsibility affect the cost of capital? Journal of Banking \& Finance, v. 35, n. 9, p. 2388-2406, 2011.

ELKINGTON, John; ROWLANDS, Ian H. Cannibals with forks: the triple bottom line of 21 st century business. Alternatives Journal, v. 25, n. 4, p. 42, 1999.

ELVING, W.; VAN VUUREN, M. Beyond identity washing: Corporate social responsibility in an age of skepticism. Akademija MM, v. 17, p. 49-55, 2011.

ESROCK, Stuart L.; LEICHTY, Greg B. Social responsibility and corporate web pages: Selfpresentation or agenda-setting? Public relations review, v. 24, n. 3, p. 305-319, 1998.

ESROCK, Stuart L.; LEICHTY, Greg B. Organization of corporate web pages: Publics and functions. Public Relations Review, v. 26, n. 3, p. 327-344, 2000.

FATEMI, Ali M.; FOOLADI, Iraj J. Sustainable finance: A new paradigm. Global Finance Journal, v. 24, n. 2, p. 101-113, 2013.

FATEMI, Ali; FOOLADI, Iraj J.; WHEELER, David. The relative valuation of socially responsible firms: An exploratory study. In: Finance for a Better World. Palgrave Macmillan, London, 2009. p. 140-167.

FELDMAN, Percy Marquina; BAHAMONDE, Rolando Arellano; VELASQUEZ BELLIDO, Isabelle. A new approach for measuring corporate reputation. Revista de Administração de Empresas, v. 54, n. 1, p. 53-66, 2014.

FREEMAN, R. Edward; WICKS, Andrew C.; PARMAR, Bidhan. Stakeholder theory and "the corporate objective revisited". Organization science, v. 15, n. 3, p. 364-369, 2004.

GARCIA-CASTRO, Roberto; ARIÑO, Miguel A.; CANELA, Miguel A. Does social performance really lead to financial performance? Accounting for endogeneity. Journal of Business Ethics, v. 92, n. 1, p. 107-126, 2010.

GILLAN, Stuart et al. Firms' environmental, social and governance (ESG) choices, performance and managerial motivation. Unpublished working paper, 2010. 
GOSS, Allen; ROBERTS, Gordon S. The impact of corporate social responsibility on the cost of bank loans. Journal of Banking \& Finance, v. 35, n. 7, p. 1794-1810, 2011.

GRAY, Rob; OWEN, Dave; ADAMS, Carol. Accounting \& accountability: changes and challenges in corporate social and environmental reporting. Prentice Hall, 1996.

HAIR, J. F. (ED.). Multivariate data analysis. 6th ed ed. Upper Saddle River, N.J: Pearson Prentice Hall, 2006.

HOMERO JUNIOR, P. F. Integrated report in Brazil: A critical reading. In: ANAIS DO USP INTERNATIONAL CONFERENCE IN ACCOUNTING, 17.2017. Anais...São Paulo: Universidade de São Paulo, 2017, 1 -18.

HOPWOOD, Anthony G.; UNERMAN, Jeffrey; FRIES, Jessica. Accounting for sustainability: Practical insights. Earthscan, 2010.

JAMALI, Dima. A stakeholder approach to corporate social responsibility: A fresh perspective into theory and practice. Journal of business ethics, v. 82, n. 1, p. 213-231, 2008.

JEUCKEN, Marcel; BOUMA, Jan Jaap. The changing environment of banks. In: Sustainable Banking. Routledge, 2017. p. 24-38.

JO, Hoje; HARJOTO, Maretno A. Corporate governance and firm value: The impact of corporate social responsibility. Journal of business ethics, v. 103, n. 3, p. 351-383, 2011.

LIANG, Kung-Yee; ZEGER, Scott L. Longitudinal data analysis using generalized linear models. Biometrika, v. 73, n. 1, p. 13-22, 1986.

LOPES, Artur Corrêa et al. Disclosure socioambiental, reputação corporativa e criação de valor nas empresas listadas na bm\&fbovespa. Revista Ambiente Contábil, v. 9, n. 1, p. $364-$ $382,2017$.

MAIGNAN, Isabelle; RALSTON, David A. Corporate social responsibility in Europe and the US: Insights from businesses' self-presentations. Journal of International Business Studies, v. 33, n. 3, p. 497-514, 2002.

MARTINS, Vinícius Gomes; DO MONTE, Paulo Aguiar. Relação do resultado abrangente com o desempenho operacional e econômico de empresas listadas no mercado brasileiro.

Revista Evidenciação Contábil \& Finanças, v. 3, n. 3, p. 19-34, 2015.

PATTEN, Dennis M. Exposure, legitimacy, and social disclosure. Journal of Accounting and public policy, v. 10, n. 4, p. 297-308, 1991.

PATTEN, Dennis M. Give or take on the internet: an examination of the disclosure practices of insurance firm web innovators. Journal of Business Ethics, v. 36, n. 3, p. 247-259, 2002. 
PATTEN, Dennis M.; CRAMPTON, William. Legitimacy and the internet: an examination of corporate web page environmental disclosures. In: Advances in Environmental Accounting \& Management. Emerald Group Publishing Limited, 2003. p. 31-57.

ROVER, Suliani et al. Explicações para a divulgação voluntária ambiental no Brasil utilizando a análise de regressão em painel. Revista de Administração- RAUSP, v. 47, n. 2 , p. 217-230, 2012.

SALTER, M. S. How Short-Termism Invites Corruption...And What to Do About it. SSRN Electronic Journal, 2012.

SCHMIDHEINY, Stephan; ZORRAQUIN, Federico; GRAY, Wayne B. Financing change: The financial community, eco-efficiency, and sustainable development. With the WORLD BUSINESS COUNCIL FOR SUSTAINABLE DEVELOPMENT. Journal of Economic Literature, v. 34, n. 4, p. 1974-1974, 1996.

SCHOLTENS, Bert. Corporate social responsibility in the international banking industry. Journal of Business Ethics, v. 86, n. 2, p. 159-175, 2009.

SERVAES, Henri; TAMAYO, Ane. The impact of corporate social responsibility on firm value: The role of customer awareness. Management science, v. 59, n. 5, p. 1045-1061, 2013.

SNIDER, Jamie; HILL, Ronald Paul; MARTIN, Diane. Corporate social responsibility in the 21st century: A view from the world's most successful firms. Journal of Business ethics, v. 48, n. 2, p. 175-187, 2003.

WIDIARTO SUTANTOPUTRA, Aries. Social disclosure rating system for assessing firms' CSR reports. Corporate Communications: An International Journal, v. 14, n. 1, p. 34-48, 2009.

TARNA, Kaisa. Reporting on the Environment. Greener Management International, n. 27, 1999.

THOMPSON, Paul; COWTON, Christopher J. Bringing the environment into bank lending: implications for environmental reporting. The British Accounting Review, v. 36, n. 2, p. 197-218, 2004.

TINKER, Tony; NEIMARK, Marilyn. The role of annual reports in gender and class contradictions at General Motors: 1917-1976. Accounting, organizations and society, v. 12, n. 1, p. 71-88, 1987.

WEBER, Olaf. Corporate sustainability and financial performance of Chinese banks. Sustainability Accounting, Management and Policy Journal, v. 8, n. 3, p. 358-385, 2017.

WEBER, Olaf; HOQUE, Asadul; AYUB ISLAM, Mohammad. Incorporating environmental criteria into credit risk management in Bangladeshi banks. Journal of Sustainable Finance \& Investment, v. 5, n. 1-2, p. 1-15, 2015. 
WEBER, Olaf; DIAZ, Michael; SCHWEGLER, Regina. Corporate social responsibility of the financial sector-Strengths, weaknesses and the impact on sustainable development.

Sustainable Development, v. 22, n. 5, p. 321-335, 2014.

WEBER, Olaf. Environmental credit risk management in banks and financial service institutions. Business Strategy and the Environment, v. 21, n. 4, p. 248-263, 2012.

WEBER, Olaf; SCHOLZ, Roland W.; MICHALIK, Georg. Incorporating sustainability criteria into credit risk management. Business strategy and the environment, v. 19, n. 1, p. 39-50, 2010.

WILLIAMS, S. Mitchell. Voluntary environmental and social accounting disclosure practices in the Asia-Pacific region: An international empirical test of political economy theory. The International Journal of Accounting, v. 34, n. 2, p. 209-238, 1999.

ZEIDAN, Rodrigo; BOECHAT, Claudio; FLEURY, Angela. Developing a sustainability credit score system. Journal of Business Ethics, v. 127, n. 2, p. 283-296, 2015. 